\title{
Predation on seven South American anuran species by water bugs (Belostomatidae)
}

\section{Luís Felipe Toledo}

Departamento de Zoologia, Instituto de Biociências, Universidade Estadual Paulista, Caixa Postal 199, 13500-970, Rio Claro, SP, Brazil. E-mail: toledolf@hotmail.com.

Keywords: Anura, predation, water bugs, Belostomatidae, Belostoma elongatum.

The risk of predation is one of the many costs related to reproduction in frogs (Howard 1981, Ryan 1985, Pough et al. 1992). Although amphibians exhibit a great diversity of defensive strategies (reviews in Duellman and Trueb 1994, Stebbins and Cohen 1997, Pough et al. 1998), anurans, in particular, are preyed upon by a great variety of arthropods, such as ants, beetles, water bugs, spiders and crabs, as well as vertebrates (fishes, other amphibians, reptiles, birds, and mammals), and even carnivorous plants (Duellman and Trueb 1994, Pough et al. 1998). A considerable amount of information has recently been collected on invertebrate predators of adult anurans (Formanowicz et al. 1981, Hinshaw and Sullivan 1990, Schiesari et al. 1995, Del-Grande and Moura 1997, Haddad and Bastos 1997, Owen and Johnson 1997, Zuffi 2001, Pramuk and Almillo 2002). Water bugs (Belostomatidae) eat tadpoles (Martins et al. 1993, Eterovick and Sazima 2000) and adult frogs (Smith 1980, Hinshaw and Sullivan 1990, Bastos et al. 1994, Haddad and Bastos 1997, Mijares-Urrutia et al. 1997). Little information is available about predation on adult frogs by Belostomatidae. Here I present new

Received 29 July 2003.

Accepted 18 November 2003.

Distributed 19 December 2003. observations of predation by water bugs, Belostoma elongatum, on adult frogs.

Field observations were made at three temporary ponds at the Estação Ecológica de Itirapina (22 13 '30'S, 47 54'19'W; $725 \mathrm{~m}$ ), Municipality of Itirapina, São Paulo state, Brazil, between November 2002 and March 2003. The ponds were no deeper than $15 \mathrm{~cm}$ and surrounded by grass and small bushes. A straight transect, $400 \mathrm{~m}$ long by $4 \mathrm{~m}$ wide was used in one of the ponds, both during the day (from 09:00 to 12:00 h) and at night (from 19:00 to 02:00 h), between 16 and 19 December. Occasional observations were also made at other times. Animals that were being preyed upon, or recently released by the bug on the water surface, identified by the characteristic circular punctures (approximately $1.5 \mathrm{~mm}$ in diameter) in the frog's skin caused by the insect's proboscis, were measured with a digital caliper to the nearest $0.01 \mathrm{~mm}$ and preserved in $70 \%$ alcohol solution. Specimens are deposited at Célio F. B. Haddad collection (CFBH 5937, 5950-60, 5962-68), Departamento de Zoologia, Universidade Estadual Paulista, Rio Claro, São Paulo state, Brazil. The belostomatids are deposited at the entomological collection of the Museu de Zoologia of the Universidade de São Paulo, Brazil (without voucher numbers).

During the study, 15 anuran species were found calling at breeding sites: Hyla 
Table 1 - Anuran species preyed upon by Belostoma elongatum at the Estação Ecológica de Itirapina between November 2002 and March 2003. SVL, snout-vent length; $X \pm$ SD, mean \pm standard deviation.

\begin{tabular}{|c|c|c|}
\hline SPECIES & $\mathrm{N}$, SEX & $\begin{array}{c}\text { SVL (mm) } \\
X \pm S D \text { (range) }\end{array}$ \\
\hline Hyla jimi & $1,0^{x}$ & 21.82 \\
\hline Hyla minuta & $1,0^{x}$ & 23.50 \\
\hline Scinax squalirostris & 1 , 우 & 19.53 \\
\hline Scinax sp. (aff. similis) & $4,0^{x}$ & $35.11 \pm 1.72(33.43-37.01)$ \\
\hline Scinax sp. (aff. similis) & 3, + gravid & $35.92 \pm 1.09(34.69-36.78)$ \\
\hline Scinax sp. (aff. similis) & $1, ?$ & 27.12 \\
\hline Leptodactylus labyrinthicus & $1, ?$ & - \\
\hline Physalaemus cuvieri & $6,0^{x}$ & $27.55 \pm 1.32(26.11-29.23)$ \\
\hline Physalaemus fuscomaculatus & $1,0^{x}$ & 41.66 \\
\hline
\end{tabular}

albopunctata, H. jimi, H. minuta, Scinax fuscomarginatus, Scinax sp. (aff. similis), $S$. squalirostris, Leptodactylus furnarius, L. fuscus, L. labyrinthicus, L. ocellatus, Physalaemus centralis, P. cuvieri, P. fuscomaculatus, $P$. nattereri, and Elachistocleis cf. ovalis. The 19 predation events by adult and nymphal water bugs (Belostoma elongatum) involved seven different species of frogs (Table 1).

Whole predation sequences upon a juvenile Leptodactylus labyrinthicus and two adult males of Scinax sp. (aff. similis) were observed. All three events were similar: the frogs were initially at the edge of the pond and, when they jumped into the water, they were immediately captured by a bug. One of the males of Scinax sp. (aff. similis) tried to escape by jumping out of the water, after being grasped by an adult $B$. elongatum. However, the water bug was firmly attached to the anuran and did not release it. The three individuals remained alive, but almost immobile, from 25 to 35 minutes after capture. On the other occasions, the frogs were found being preyed upon or just after having been killed by water bugs. All predation events occurred on the water surface and the frogs were strongly held by the forelimbs of the water bugs. The bugs did not hold the frog in any specific part of the body. B. elongatum individuals were found throughout the night and predation events occurred between 21:15 and 00:05 h, coinciding with the peak of calling activity of the frogs. During the day, four dead frogs [two Scinax sp. (aff. similis) and two P. cuvieri] were found floating on the water surface with leptodactylid tadpoles feeding on their internal organs.

Males of the genus Physalaemus found at the study site called while floating on the water surface on the edges of temporary ponds. Hence, the production of waves may have attracted aquatic predators such as water bugs (Pough et al. 1992) (Figure 1A). Moreover, the proportion of females, in relation to males, in the site was very low (pers. obs.), suggesting why only males were preyed upon. The only Leptodactylus sp. preyed upon was a juvenile L. labyrinthicus that jumped into the water (Figure 1B). The other species of the genus were observed calling on the ground, strongly reducing the risk of predation by these insects. Hylid frogs have been also observed calling at dry sites, on the ground [(Scinax sp. (aff. similis)] or from shrubs 

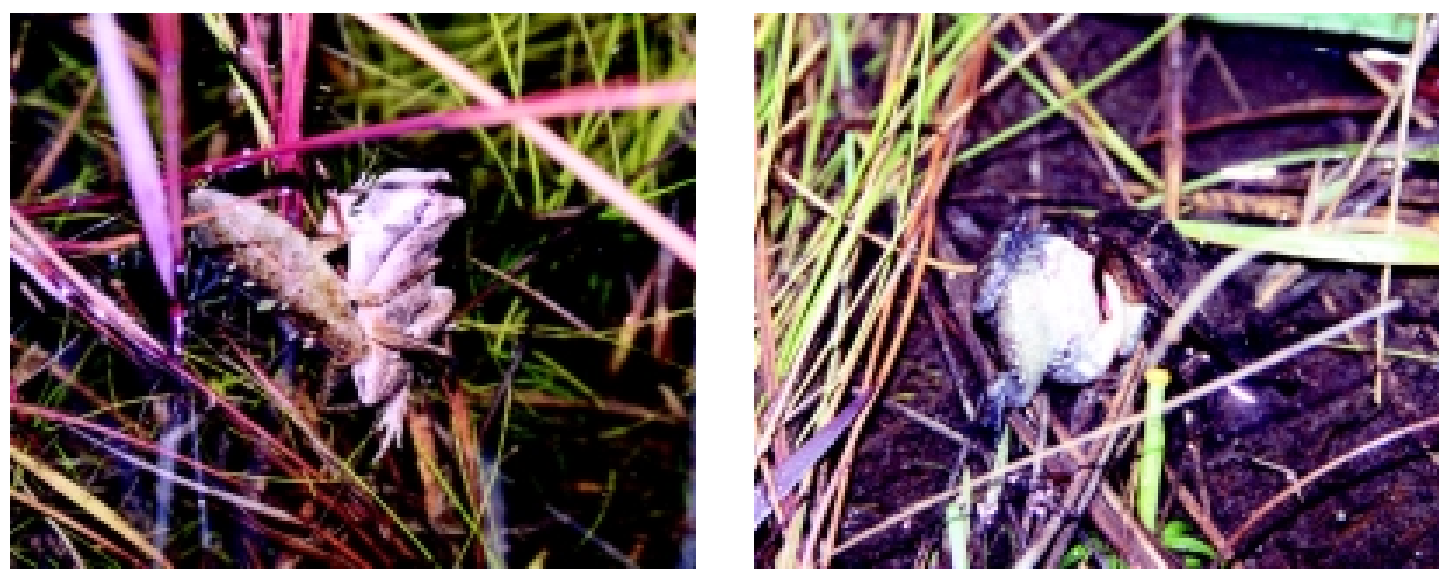

Figure 1 - Adult male Physalaemus cuvieri (A) and juvenile Leptodactylus labyrinthicus (B) being preyed upon by water bug Belostoma elongatum in temporary ponds at Estação Ecológica de Itirapina, São Paulo state, Brazil.

above the ground or the water (all hylid species). However, being highly dependent on water bodies for reproduction, all observed species must have direct contact with water at least during oviposition (Lutz 1973).

Water bugs appear to be the major invertebrate predators of adult frogs in Estação Ecológica de Itirapina as no other predation event was observed during the entire reproductive season at the temporary ponds I studied or other breeding sites I visited occasionally.

\section{Acknowledgements}

I thank Célio F. B. Haddad, Anne d'Heursel, Günter Gollmann, Jaime Bertoluci, and two anonymous referees for revising the manuscript and making helpful suggestions, Carlos Campaner for identifying the water bugs, Débora Campos and Juliana Zina for helping in the field. The author is also grateful to $\mathrm{CNPq}$ for financial support, Idea Wild for equipment donation, IBAMA, IF, and Denise Zancheta for the permissions conferred.

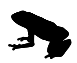

\section{References}

Bastos, R. P., O. C. Oliveira and J. P. Pombal Jr. 1994. Hyla minuta (NCN). Predation. Herpetological Review 25: 118 .

Del-Grande, M. L. and G. Moura. 1997. Hyla sanborni (NCN). Predation. Herpetological Review 28: 147.

Duellman, W. E. and L. Trueb. 1994. Biology of Amphibians. 2nd ed. Baltimore and London. The John Hopkins University Press. 670 pp.

Eterovick, P. C. and I. Sazima. 2000. Structure of an anuran community in a montane meadow in southeastern Brazil: effects of seasonality, habitat, and predation. Amphibia-Reptilia 21: 439-461.

Formanowicz Jr., D. R., M. M. Srewart, K. Townsend, F. H. Pough, and P. F. Brussard. 1981. Predation by giant crab spiders on the Puerto Rican frog Eleuterodactylus coqui. Herpetologica 37: 125-129.

Haddad, C. F. B. and R. P. Bastos. 1997. Predation on the toad Bufo crucifer during reproduction (Anura: Bufonidae). Amphibia-Reptilia 18: 295-298.

Hinshaw, S. H. and B. K. Sullivan. 1990. Predation on Hyla versicolor and Pseudacris crucifer during reproduction. Journal of Herpetology 24: 196-197.

Howard, R. D. 1981. Sexual dimorphism in bullfrogs. Ecology 62: 303-310.

Lutz, B. 1973. Brazilian Species of Hyla. Austin. University of Texas Press. 260 pp. 
Martins, M., I. Sazima and S. G. Egler. 1993. Predators of the nest building gladiator frog, Hyla faber, in southeastern Brazil. Amphibia-Reptilia 14: 307-309.

Mijares-Urrutia, A., A. Arends and J. M. Hero. 1997. Hyla crepitans $(\mathrm{NCN})$. Predation. Herpetological Review 28: 84 .

Owen, R. D. and S. A. Johnson. 1997. Pseudacris ocularis (Little Grass Frog). Predation. Herpetological Review 28: 200

Pough, F. H., R. M. Andrews, J. E. Cadle, A. H. Savitzky, and K. D. Wells. 1998. Herpetology. New Jersey. Prentice Hall. 577 pp.

Pough, F. H., W. E. Magnusson, M. J. Ryan, K. D. Wells, and T. L. Taigen. 1992. Behavioral energetics. Pp. 395436 in M. E. Feder and W. W. Burggren (eds.), Environmental Physiology of the Amphibians. Chicago. University of Chicago Press.
Pramuk, J. B. and H. Almillo. 2002. Hyla nana. Predation. Herpetological Review 33: 46-47.

Ryan, M. J. 1985. The Tungara Frog. Chicago. University of Chicago Press. 230 pp.

Schiesari, L. C., F. A. Juncá and G. M. Accacio. 1995. Hylodes phyllodes (NCN). Predation. Herpetological Review 26: 30-31.

Smith, R. L. 1980. Daddy water bug. Natural History 89: 56-63.

Stebbins, R. C. and N. W. Cohen. 1997. A Natural History of Amphibians. New Jersey. Princeton University Press. 316 pp.

Zuffi, M. A. 2001. Bufo bufo (European Common Toad). Red ant predation. Herpetological Review 32: 100101. 